\title{
Arabic Language Surveys Measuring Mothers' Satisfaction During Childbirth: A Review
}

\author{
Waleed Al Nadabi ${ }^{1} \&$ Mohammed A Mohammed ${ }^{1}$ \\ ${ }^{1}$ Faculty of Health Studies, University of Bradford, Bradford, United Kingdom \\ Correspondence: Waleed Al Nadabi, Faculty of Health Studies, University of Bradford, Bradford, United \\ Kingdom. Tel: 44-777-867-2181. E-mail: w.k.a.alnadabi@bradford.ac.uk
}

Received: February 21, 2019 Accepted: May 10, 2019 Online Published: May 20, 2019

doi:10.5539/gjhs.v11n6p169

URL: https://doi.org/10.5539/gjhs.v11n6p169

\begin{abstract}
Purpose: To review Arabic surveys used to measure maternal satisfaction.

Methodology: Peer-reviewed studies published in English and Arabic since 2000 were reviewed across eight databases. Surveys were assessed by: survey construction, reliability, and validity.

Findings: The seven studies that met the inclusion criteria were in English and included seven different Arabic surveys. Survey items ranged from eight to 32 and were translated from English (3/7) or were originally written in Arabic (4/7). Six surveys were pilot tested. Dimensions covered by the surveys varied but all measured satisfaction about providers' interpersonal care. Internal reliability was reported for four surveys and none reported the test-re-test results. Three studies reported content validity, one reported face validity, one reported construct validity, and none reported criterion validity. Participants' inclusion criteria varied but all studies excluded women with still births or obstetric complications. When surveyed within hospital (3/7), participants were approached within 72 hours after delivery while those surveyed outside the hospital were approached two weeks, seven weeks, or two months after discharge. Overall, the eight-item survey was found short, well tested with good psychometric properties.
\end{abstract}

Conclusions: The psychometric properties of Arabic surveys were determined in limited settings, were not well reported, and varied. The eight-item survey is a well-tested survey with good psychometric properties. Furthermore, rigorous evaluation of Arabic surveys in different contexts with wider inclusion criteria is required. Our findings will promote further research in this area and will help enhance maternal experience with childbearing.

Keywords: women satisfaction, Arabic survey, Arabic questionnaire, birth, measurement, literature review

\section{Introduction}

Childbearing is the most common reason for utilising health services and the continual measurement and enhancement of the quality and safety of maternity care is a global concern. An important indicator of the quality of maternity care is patient (women's) satisfaction with the care provided, especially during delivery. Satisfaction with maternity care is linked to positive outcomes for the mother and child and affects how users seek medical assistance and their compliance to medical advice (Carr-Hill, 1992; Draper, Cohen, \& Buchan, 2001; Harvey, Rach, Stainton, Jarrell, \& Brant, 2002). So, women's satisfaction with their childbirth experience is very important to providers, administrators and policy makers (Sitzia \& Wood, 1997) not only in evaluating and improving care (Crow et al., 2002), but also in planning how care should be provided (Van Teijlingen, Hundley, Rennie, Graham, \& Fitzmaurice, 2003).

\subsection{What Is Patient Satisfaction?}

Although many researchers emphasise the importance of measuring patient satisfaction, there is no consensus on the definition of satisfaction, the factors that affect satisfaction and the tools to measure satisfaction, because patient satisfaction is a complex, multidimensional construct that is subjectively (not objectively) evaluated by those who received care (Carr-Hill, 1992; Crow et al., 2002; Harvey et al., 2002). Ware, Snyder, Wright, and Davies (1983) defined satisfaction as “"personal evaluation of healthcare services and providers' while Linder-Pelz and Struening (1985) defined it as 'multiple evaluations of distinct aspects of healthcare which are determined (in some way) by the individual's perceptions, attitudes and comparison processes'. Despite these challenges, Crow et al. (2002) contend that patient satisfaction remains an important indicator of quality of care 
and its measurement is growing in different parts of the world. The authors state that the word 'satisfaction' is derived from Latin - meaning 'enough' which indicates two key characteristics. First, when a patient is satisfied it means that an acceptable (enough) level of care was attained. Second, measuring satisfaction can only be examined against the expectations/needs of the patients. According to Lam, Banihashem, Lam, Wan, and Chow (2019), terms like expectation, perception and satisfaction refer to the subjective evaluation of patient while experience refers to objective evaluation of health services. In this paper, the term satisfaction will be used to refer to the patients' subjective evaluation of health services.

\subsection{How to Measure Satisfaction?}

There are several approaches to measuring patient satisfaction like surveys, interviews, focus group discussion, critical incident analysis, complaints, matron rounds, telephone calls, and ward meetings (Carr-Hill, 1992). Whilst each of these methods has its strengths and limitations, surveys are perhaps the most popular method for measuring satisfaction especially as surveys are relatively low cost, high volume, and can be used objectively and practically to measure the change in satisfaction over time (Sitzia \& Wood, 1997). Interviews and focus group discussions can provide and in-depth information from participants (Crow et al., 2002) but compared with surveys, they are usually undertaken with smaller groups and so their results are less likely to be generalisable.

A number of systematic reviews have looked into the surveys for examining women's satisfaction with maternity care. The systematic review by Perriman and Davis (2016) looked specifically at surveys used to measure satisfaction of mothers with continuity of care in the maternity care. They identified four surveys with varying degrees of reliability and validity. Similarly, Sawyer et al. (2013) reviewed the literature for surveys that were used to examine satisfaction of the mother with care during labour and birth. They found nine surveys with varying levels of reliability and validity.

Despite the extensive work related to satisfaction of mothers to maternity care, little is known about the Arabic surveys available to measure satisfaction. There are 26 countries where Arabic is officially recognized by the government, with 18 having a majority of their people using it as their first language (Worldatlas, 2018). A recent review by Hussein, Dahlen, Ogunsiji, and Schmied (2018) examined the studies related to satisfaction in the Middle East but did not assess the quality of the surveys but rather focused on identifying components of satisfaction. In addition, their review included Arabic and non-Arabic surveys.

Our aim is to undertake a review of surveys available in the Arabic language that have been used to measure satisfaction of women about their care during childbirth. The specific objectives of our review were (a) to describe the different surveys used to measure satisfaction, (b) to report the quality of these surveys, and (c) To examine the different dimensions of satisfaction measured by these surveys.

\section{Methods}

This paper used a systematic approach to review the literature published on or before 2000-2018 across six electronic databases.

\subsection{Review Protocol}

See Table 1 for the review protocol

Table 1. Review protocol

\begin{tabular}{|c|c|c|}
\hline & Inclusion criteria & Exclusion criteria \\
\hline Population & Post-partum Arabic women in Arabic countries & Pregnant women \\
\hline Intervention & Assessment of satisfaction & $\begin{array}{l}\text { Assessment of knowledge or awareness or views about a } \\
\text { test or abortion }\end{array}$ \\
\hline Comparator & None & \\
\hline Outcomes & Satisfaction or experience & Knowledge or awareness \\
\hline Study & Quantitative using a survey & Mixed method, qualitative \\
\hline
\end{tabular}

\subsection{Data Sources}

The search engines used for this literature review were: Cumulative Index to Nursing and Allied Health Literature (CINAHL); Embase; the Health Management Information Consortium (HMIC); Medline; Psych INFO; Allied and Complementary Medicine Database (AMED). 


\subsection{Search Strategy}

Search terms were first used in Medline and applied to other databases. The search strategy combined relevant terms as follows: (terms related to maternity care) AND (terms related to satisfaction) AND (terms related to women) AND (terms related to Arabs). Table 2 shows the search terms used as keywords in Medline and replicated to other databases.

Table 2. Search terms

\begin{tabular}{llll}
\hline $\begin{array}{l}\text { Search terms for } \\
\text { maternity units }\end{array}$ & $\begin{array}{l}\text { Search terms for } \\
\text { satisfaction }\end{array}$ & $\begin{array}{l}\text { Search terms } \\
\text { for users }\end{array}$ & Search terms for Arabs \\
\hline $\begin{array}{l}\text { Matern* or midwif*or } \\
\text { midwive* or perinatal or } \\
\text { postnatal or antenatal or } \\
\text { pregnancy or birth or }\end{array}$ & $\begin{array}{l}\text { Satisfaction or } \\
\text { experience or perception } \\
\text { or attitude or views or } \\
\text { labour or labor }\end{array}$ & $\begin{array}{l}\text { user or women } \\
\text { or patient }\end{array}$ & $\begin{array}{l}\text { Arab or Arab countries or Arab world or Algeria } \\
\text { or Bahrain or Egypt or Iraq or Jordan or Kuwait } \\
\text { or Lebanon or Libya or Mauritania or Morocco or } \\
\text { Oman or Palestine or Qatar or Saudi Arabia or } \\
\text { Sudan or Syria or Tunisia or United Arab }\end{array}$ \\
\hline
\end{tabular}

\subsection{Inclusion Criteria}

Studies needed to be peer reviewed and conducted in Arabic countries to measure patient satisfaction about care received during child birth. To be included, studies needed to be using a survey written in Arabic. Search was limited to studies published in English or Arabic on or after 2000.

\subsection{Exclusion Criteria}

Studies that only examined satisfaction about care during antenatal period or were focused on views about pain management during labour or perception about breastfeeding, abortion, or family planning were excluded. Additionally, qualitative studies and studies examining satisfaction of Arabic women who migrated to non-Arab countries were also excluded. Thesis and grey literature were not considered for this review.

\subsection{Data Extraction and Quality Assessment}

Data extraction and data synthesis were performed simultaneously using tables to summarize key information and results (Table 3 Appendix 1). The quality of surveys included in the review was guided by the criteria used by Sawyer et al. (2013) and three main categories were used: survey construction (item generation and pilot testing), reliability (internal consistency and test-retest), and validity (face, content, criterion, and construct). The detailed items under each criteria and its description can be found in their paper. In this review, the quality assessments of the surveys are described as reported by the authors. However, if the survey used was translated from an English tool, an attempt is made to retrieve the original article describing the tool. Thus, it will be noticed that two Cronbach Alpha values might be reported for the translated survey, one value for the Arabic version and the other one for the English version.

\section{Findings}

Conducted in March 2018, a total of 1211 articles were retrieved across eight databases. After removing duplicates, 924 articles were left. The remaining articles were scanned for eligibility through the title and abstract. Out of 23 articles considered for full text review, only seven studies were included and the other 15 studies were excluded (See Table 3 and Appendix 2). One study that was considered for full text review was excluded because the full text was not accessible even after contacting the author (Monazea \& Al-Attar, 2015). The seven studies included used different surveys ending up with seven different surveys. Figure 1 summarizes the search strategy and selection process using the Preferred Reporting Items for Systematic Reviews and Meta-Analyses (PRISMA) statements (Liberati et al., 2009; Moher, Liberati, Tetzlaff, Altman, \& The, 2009). The following sections will describe the seven surveys found by this review and their psychometric properties. 


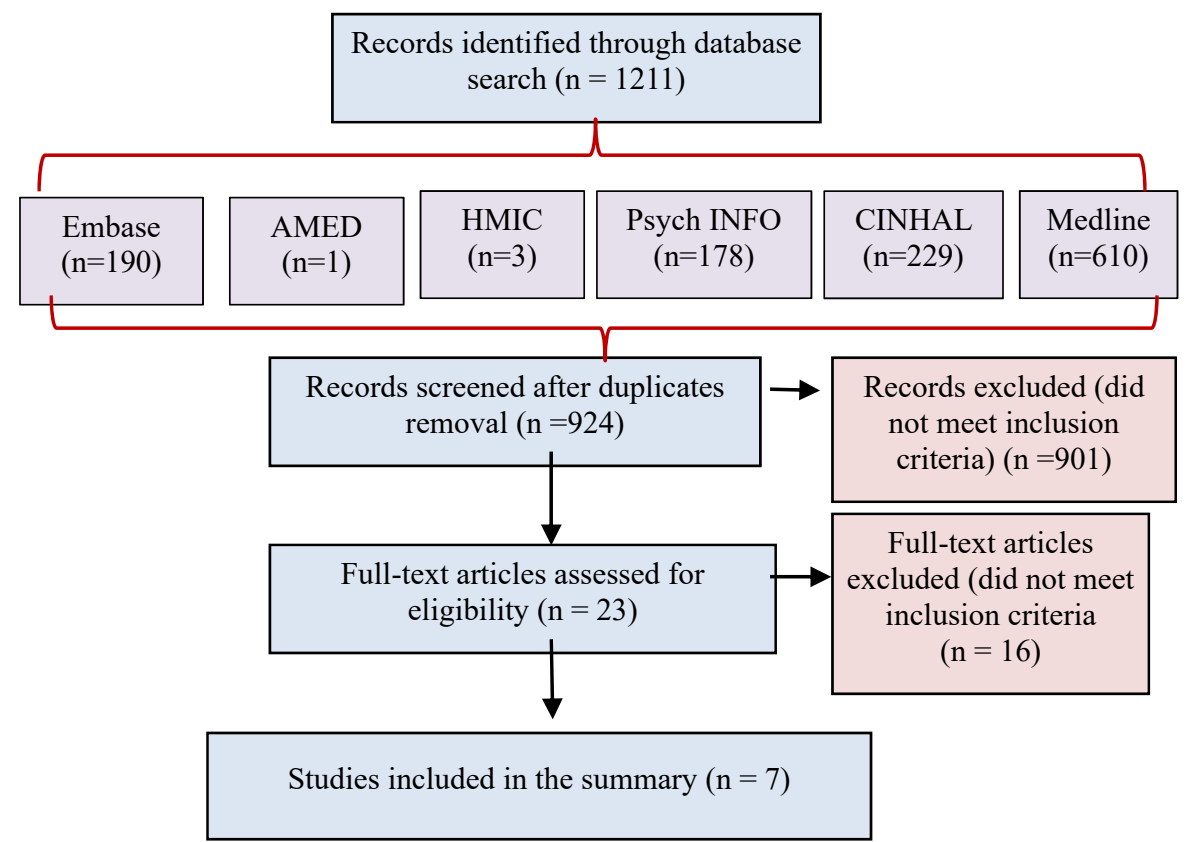

Figure 1. Search strategy and selection process PRISMA flow chart

Table 3. Summary of studies included in the review

\begin{tabular}{|c|c|c|c|c|c|c|c|}
\hline \multirow{2}{*}{ Author } & \multirow{2}{*}{ Country } & \multicolumn{3}{|c|}{ Participants } & \multirow{2}{*}{$\begin{array}{l}\text { Original } \\
\text { language }\end{array}$} & \multirow{2}{*}{$\begin{array}{l}\text { Where } \\
\text { surveyed }\end{array}$} & \multirow{2}{*}{$\begin{array}{l}\text { When } \\
\text { surveyed }\end{array}$} \\
\hline & & Number & Included & Excluded & & & \\
\hline $\begin{array}{l}\text { (D. E. Rizk, Nasser, } \\
\text { Thomas, \& Ezimokhai, } \\
\text { 2001) }\end{array}$ & $\begin{array}{l}\text { United } \\
\text { Arab } \\
\text { Emirates } \\
\text { (UAE) }\end{array}$ & 715 & $\begin{array}{l}\text { Women who } \\
\text { delivered } \\
\text { normal and } \\
\text { caesarean } \\
\text { section }\end{array}$ & $\begin{array}{l}\text { Women with still } \\
\text { birth babies, staff } \\
\text { in the hospital, or } \\
\text { had history of } \\
\text { psychiatric illness. }\end{array}$ & Arabic & $\begin{array}{l}\text { At the } \\
\text { hospital }\end{array}$ & $\begin{array}{l}\text { On the third } \\
\text { postnatal } \\
\text { day }\end{array}$ \\
\hline $\begin{array}{l}\text { (Mosallam, Rizk, } \\
\text { Thomas, \& Ezimokhai, } \\
\text { 2004) }\end{array}$ & (UAE) & 400 & $\begin{array}{l}\text { Singleton } \\
\text { normal } \\
\text { pregnancies } \\
\text { delivered } \\
\text { vaginally }\end{array}$ & $\begin{array}{l}\text { Women with } \\
\text { multiple pregnancy } \\
\text { and significant } \\
\text { obstetric } \\
\text { complications and } \\
\text { delivered by } \\
\text { caesarean }\end{array}$ & Arabic & $\begin{array}{l}\text { At the } \\
\text { hospital }\end{array}$ & $\begin{array}{l}\text { On the third } \\
\text { postnatal } \\
\text { day }\end{array}$ \\
\hline (Oweis, 2009) & Jordan & 177 & $\begin{array}{l}\text { Literate women } \\
\text { with healthy } \\
\text { baby, by normal } \\
\text { vaginal delivery } \\
\text { and assisted } \\
\text { delivery }\end{array}$ & $\begin{array}{l}\text { Not explicitly } \\
\text { reported }\end{array}$ & Arabic & $\begin{array}{l}\text { At the } \\
\text { primary } \\
\text { health-care } \\
\text { centres }\end{array}$ & $\begin{array}{l}\text { Not } \\
\text { reported }\end{array}$ \\
\hline (Bashour et al., 2013) & Syria & 2000 & $\begin{array}{l}\text { Women who } \\
\text { gave birth to a } \\
\text { living baby } \\
\text { (vaginal birth or } \\
\text { by caesarean } \\
\text { section) }\end{array}$ & $\begin{array}{l}\text { Women with } \\
\text { difficult labour and } \\
\text { high-risk } \\
\text { pregnancies }\end{array}$ & English & At home & $\begin{array}{l}\text { Within } 2 \\
\text { weeks after } \\
\text { delivery }\end{array}$ \\
\hline
\end{tabular}




\begin{tabular}{|c|c|c|c|c|c|c|c|}
\hline $\begin{array}{l}\text { (Mohammad, Alafi, } \\
\text { Mohammad, Gamble, \& } \\
\text { Creedy, 2013) }\end{array}$ & Jordan & 320 & $\begin{array}{l}\text { Who were } 7 \\
\text { weeks } \\
\text { post-partum and } \\
\text { had a term live } \\
\text { baby. }\end{array}$ & $\begin{array}{l}\text { Women who had } \\
\text { still birth or } \\
\text { preterm baby }\end{array}$ & English & $\begin{array}{l}\text { In a } \\
\text { convenient } \\
\text { location }\end{array}$ & $\begin{array}{l}7 \quad \text { weeks } \\
\text { postpartum }\end{array}$ \\
\hline $\begin{array}{l}\text { (Shaban, Mohammad, \& } \\
\text { Homer, 2016) }\end{array}$ & Jordan & 300 & $\begin{array}{l}\text { Low-risk } \\
\text { women who } \\
\text { gave birth to a } \\
\text { singleton } \\
\text { healthy baby at } \\
\text { term }\end{array}$ & $\begin{array}{l}\text { Women who had a } \\
\text { stillbirth or } \\
\text { neonatal death in } \\
\text { their most recent } \\
\text { birth }\end{array}$ & Arabic & $\begin{array}{l}\text { At the } \\
\text { primary } \\
\text { health-care } \\
\text { centres }\end{array}$ & $\begin{array}{l}\text { Within } \\
\text { months }\end{array}$ \\
\hline $\begin{array}{l}\text { (Kabakian-Khasholian } \\
\text { et al., 2017) }\end{array}$ & $\begin{array}{l}\text { Egypt, } \\
\text { Lebanon } \\
\text { and Syria }\end{array}$ & 2620 & $\begin{array}{l}\text { Women who } \\
\text { gave birth in the } \\
\text { hospitals } \\
\text { studied }\end{array}$ & $\begin{array}{l}\text { Women classified } \\
\text { as high-risk, those } \\
\text { who suffered from } \\
\text { intrauterine foetal } \\
\text { death and those } \\
\text { below } 18 \text { years }\end{array}$ & English & $\begin{array}{l}\text { At the } \\
\text { hospital }\end{array}$ & $\begin{array}{l}6 \text { to } 48 \\
\text { hours after } \\
\text { giving birth }\end{array}$ \\
\hline
\end{tabular}

\subsection{An Overview of the Included Studies}

Three studies were conducted in Jordan, two in the United Arab Emirates, one in Syria, and another study that was conducted in three countries (Egypt, Lebanon, and Syria). Three surveys were translated from English while the other four were developed in Arabic. The number of participants ranged from 177 to 2620 women. The timing of the study varied from 6 hours after discharge to 2 months after discharge. No study reported the effect of timing on the psychometric properties of the surveys. Three studies were conducted at the hospital, two at the primary health care centre, one at home, and one in a convenient place away from the clinic. Almost all studies excluded women who had still birth or obstetric complications. None of the studies included the Arabic version of the survey in their paper. When reported, all surveys used 5 points rating scale. The following sections describe each survey's psychometric properties as summarized in Appendix 1.

\subsection{Modified Medical Interview Satisfaction Scale (MMISS)}

This is a 21-item survey covering the doctor-women relationship in delivery rooms. The Arabic version of the MMISS survey was developed by Bashour et al. (2013) to evaluate the training course impact on the communication skills of health care providers in Syria as perceived by women who were surveyed at home two weeks after delivery. Participants included those who had vaginal and caesarean delivery. The survey was originally developed in the United States to measure satisfaction about communication and was not specifically designed for maternity care. The original version had limited evidence about its reliability and validity but the British modified version of the survey had a good internal consistency with a Cronbach's Alpha ranging from 0.67 to 0.92 (Meakin \& Weinman, 2002). However, the steps used to translate the tool and the psychometric properties of the Arabic version were not reported by Bashour et al. (2013).

\subsection{Adapted Version of the Mackey Childbirth Satisfaction Rating Scale (MCSRS)}

The Arabic version of the MCSRS has 31 items and was developed by Kabakian-Khasholian et al. (2017) to assess satisfaction of women who were surveyed just before their discharge in Syria, Egypt, and Lebanon. The survey covered six dimensions measuring aspects related to self, partner, baby, nurse/midwife, physician, and general rating scale. The MCSRS was used along with the Labour Agentry Scale (LAS) that was used to assess the perceived control during childbirth. The MCSRS was originally designed by Mackey and Goodman and was found to have a strong internal reliability with a Cronbach alpha ranging from 0.7 to 0.97 (Moudi \& Tavousi, 2016). Although Kabakian-Khasholian et al. (2017) cited that the Cronbach Alpha for the Arabic version was found to be 0.95 , the full text of the cited reference was not accessible and no sufficient information was not reported in the abstract. Thus, no comments could be made about its reliability, validity or the translation process.

\subsection{Satisfaction With Childbirth Care Scale (SCCS)}

The SCCS is an 8-item survey developed by Mohammad et al. (2013) who surveyed Jordanian women seven weeks after delivery in a convenient location away from the clinic. This seven weeks period was reported by the authors to be an opportunity for mothers to reflect upon their experience. The SCCS items covered two dimensions: interpersonal care (four items) and information received and involvement (four items). The survey was pilot tested with 20 childbearing women before being used in the study. The Cronbach Alpha for SCCS is 0.81 
and a panel of experts assessed its content validity while the face validity was assessed by 20 childbearing women. The SCCS was originally written in English and the back translation process to Arabic was conducted by four scholars to ensure content and semantic validity.

\subsection{7-Items Survey}

This survey was developed originally in the Arabic language in the United Arab Emirates (UAE) by Mosallam et al. (2004). The survey items were generated using literature review and were pilot tested on 20 women to assess for clarity and suitability. However, no information was reported about reliability and validity of the survey. Participating women were surveyed on their third day postnatally excluding those who had caesarean section. The survey covered mothers' views about the psychological support and antenatal preparation as well as their overall satisfaction.

\subsection{Satisfaction With Childbirth Experience (SWCBE)}

Oweis (2009) developed this 32 item survey in Arabic language after a literature review but the dimensions covered were not explicitly reported. It was used in Jordan and was piloted in 30 women to test for clarity. The SWCBE face validity was tested by three nursing experts and it has a good internal reliability with a Cronbach Alpha of 0.88 . However, the authors suggested the need for further studies to assess the reliability of the survey on a larger sample size. Additionally, participants were selected based on a convenience sample and this may affect not only the generalizability of the results but also the psychometric properties of the survey. This survey was used along with another tool (women's perception of control during childbirth) that assessed the perceived control during childbirth.

\subsection{3-Item Survey}

This is a 23 items survey developed and used by D. E. Rizk et al. (2001) in the United Arab Emirates. The survey items were developed after literature review and were pilot tested on 20 women to assess for clarity and ease of administration. The dimensions covered by the survey were not reported. Both normal and caesarean delivery women were included in the study. Women were surveyed on their third day postnatally. However, women who had a still birth or had a history of psychiatric illness were excluded from the study. The reliability and validity of the survey were not reported.

\subsection{4-Items Survey}

Shaban et al. (2016) developed this 14 item survey originally in Arabic language and used it in Jordan. It measured three dimensions of care: Interpersonal care, information and involvement, and physical birth environment. The items of the survey were informed by literature review and were tested by 20 women to assess the clarity and readability of the items. It has a good internal reliability with a Cronbach Alpha of 0.88. A panel of seven clinicians assessed the content validity of survey items. Construct validity was tested and found that no items were removed due to redundancy and all items had factor loading of 0.53 or on at least one factor. The authors reported that participants were surveyed at the primary care centre within two months after delivery. Their rational for the period was that to allow sufficient duration to adapt after delivery but close enough to remember the event.

\section{Discussion}

This review has examined the Arabic language surveys that were used to measure satisfaction of women about the care received during childbirth in Arab countries. It has shown that there are only seven studies met the inclusion criteria. These studies were published in five Arabic countries. Four of these studies used surveys that were originally developed in the Arabic language while the other three were translated from an English survey. The number of participants surveyed in the studies ranged from 177 to 2620 . In addition, the criteria used to include or exclude participants were different. For example, Bashour et al. (2013) and D. E. Rizk et al. (2001) included both normal and caesarean deliveries while Mosallam et al. (2004), Oweis (2009) and Shaban et al. (2016) only included women who delivered vaginally and had a singleton normal baby. The time period of conducting the study ranged from 6 hours (Kabakian-Khasholian et al., 2017) to 2 months post-delivery (Shaban et al., 2016).

The SCCS is a short survey ( 8 items) with a good reliability and has face and content validity. Another relatively short (14 items) and well tested tool that has good psychometric properties is the 14-items survey developed by (Shaban et al., 2016). The SWCBE has a good internal reliability and content validated and it can be used in studies aiming to examine satisfaction and control during childbirth. It should be noted, however, that the timing of conducting the study and the included participants should be taken into consideration as the psychometric properties of these surveys might not apply when used at different timings and with different inclusion and exclusion criteria.

Similar to what has been found by Sawyer et al. (2013), the extent to which the surveys were tested for psychometric properties varied greatly. Only four studies reported the reliability while the face validation was 
reported by only one study, the content validity was reported by three studies, and the construct validity was reported by one study. Although the English version surveys were tested for their internal reliability, this doesn't ensure that the translated Arabic version will have an equivalent reliability (Maneesriwongul \& Dixon, 2004). Thus, studies aiming to adopt an existing survey in another language, should report the psychometric properties of the survey even if the original survey had an established reliability and validity.

\subsection{Limitations}

Our review has two main limitations. First, as grey literature was not considered in this review, relevant studies might have been missed. Second, important studies published in other databases could be missed despite the multiple databases used for this review.

\section{Conclusion}

Our review concludes that there are few surveys with varying psychometric properties available for use in an Arabic context. Decision maker, health care providers, and researchers should consider these properties, the settings under which they were tested and the dimensions covered before selecting a survey. Our review calls for Arabic surveys that are rigorously evaluated in different contexts with wider inclusion criteria that can be used to measure mother's satisfaction about their childbearing experience. Our findings will promote further research in this area and will help enhance maternal experience with childbearing.

\section{Competing Interests Statement}

The authors declare that there are no competing or potential conflicts of interest.

\section{References}

Awadalla, H. I., Kamel, E. G., Mahfouz, E. M., \& Refaat, T. M. (2009). Evaluation of maternal and child health services in El-Minia City, Egypt. Journal of Public Health, 17(5), 321-329. https://doi.org/10.1007/s10389-009-0255-8

Bashour, H. N., Kanaan, M., Kharouf, M. H., Abdulsalam, A. A., Tabbaa, M. A., \& Cheikha, S. A. (2013). The effect of training doctors in communication skills on women's satisfaction with doctor-woman relationship during labour and delivery: A stepped wedge cluster randomised trial in Damascus. BMJ Open, 3(8). http://dx.doi.org/10.1136/bmjopen-2013-002674

Benage, M., Greenough, P. G., Vinck, P., Omeira, N., \& Pham, P. (2015). An assessment of antenatal care among Syrian refugees in Lebanon. Conflict and Health, 9(8). https://doi.org/10.1186/s13031-015-0035-8

Bougmiza, I., Ghardallou, E. L. M., Zedini, C., Lahouimel, H., Nabli-Ajmi, T., Gataa, R., . . Mtiraoui, A. (2011). Assessment of patient satisfaction in hospital gynecology obstetrics Sousse, Tunisia. Pan African Medical Journal, 8(44). https://www.dx.doi.org/10.11604/pamj.2011.8.44.469

Carr-Hill, R. A. (1992). The measurement of patient satisfaction. Journal of Public Health, 14(3), 236-249. https://doi.org/10.1093/oxfordjournals.pubmed.a042739

Crow, H., Gage, H., Hampson, S., Hart, J., Kimber, A., Storey, L., \& Thomas, H. (2002). Measurement of satisfaction with health care: Implications for practice from a systematic review of the literature. Health technology assessment, 6(32). https://doi.org/10.3310/hta6320

Draper, M., Cohen, P., \& Buchan, H. (2001). Seeking consumer views: what use are results of hospital patient satisfaction surveys? International Journal for Quality in Health Care, 13(6), 463-468. https://doi.org/10.1093/intqhe/13.6.463

Ghobashi, M., \& Khandekar, R. (2008). Satisfaction among Expectant Mothers with Antenatal Care Services in the Musandam Region of Oman. Sultan Qaboos University Medical Journal, 8(3), 325-332.

Harvey, S., Rach, D., Stainton, M. C., Jarrell, J., \& Brant, R. (2002). Evaluation of satisfaction with midwifery care. Midwifery, 18(4), 260-267. http://dx.doi.org/10.1054/midw.2002.0317

Hussein, S., Dahlen, H. G., Ogunsiji, O., \& Schmied, V. (2018). Women's experiences of childbirth in Middle Eastern countries: A narrative review. Midwifery, 59, 100-111. https://doi.org/10.1016/j.midw.2017.12.010

Kabakian-Khasholian, T., Bashour, H., El-Nemer, A., Kharouf, M., Sheikha, S., El Lakany, N., .. . Portela, A. (2017). Women's satisfaction and perception of control in childbirth in three Arab countries. Reproductive Health Matters, 25(sup1), 16-26. https://doi.org/10.1080/09688080.2017.1381533

Kamil, A., \& Khorshid, E. (2013). Maternal perceptions of antenatal care provision at a tertiary level hospital, riyadh. Oman Medical Journal, 28(1), 33-35. https://dx.doi.org/10.5001\%2Fomj.2013.07

Kempe, A., Noor-Aldin Alwazer, F. A., \& Theorell, T. (2010). Women's authority during childbirth and Safe 
Motherhood in Yemen. Sexual \& Reproductive Healthcare, 1(4), 129-134. https://doi.org/10.1016/j.srhc.2010.07.001

Khresheh, R. (2010). Support in the first stage of labour from a female relative: the first step in improving the quality of maternity services. Midwifery, 26(6), e21-e24. https://doi.org/10.1016/j.midw.2008.11.003

Khresheh, R., Almalik, M., Owies, A., \& Barclay, L. (2018). Implementation of a childbirth preparation program in the maternal and child health centres in Jordan. Midwifery, 61, 1-7. https://doi.org/10.1016/j.midw.2018.02.010

Lam, M. T., Banihashem, M., Lam, H. R., Wan, A. B., \& Chow, E. (2019). Patient experience, satisfaction, perception and expectation of osteopathic manipulative treatment: A systematic review. International Journal of Osteopathic Medicine. https://doi.org/10.1016/j.ijosm.2019.04.003

Langer, A., Villar, J., Romero, M., Nigenda, G., Piaggio, G., Kuchaisit, C., . . Berendes, H. (2002). Are women and providers satisfied with antenatal care? Views on a standard and a simplified, evidence-based model of care in four developing countries. BMC Women's Health, 2(1). https://dx.doi.org/10.1186\%2F1472-6874-2-7

Liberati, A., Altman, D. G., Tetzlaff, J., Mulrow, C., Gotzsche, P. C., Ioannidis, J. P., . . Moher, D. (2009). The PRISMA statement for reporting systematic reviews and meta-analyses of studies that evaluate health care interventions: explanation and elaboration. PLoS Med, 6(7). https://doi.org/10.1371/journal.pmed.1000100

Linder-Pelz, S., \& Struening, E. L. (1985). The multidimensionality of patient satisfaction with a clinic visit. Journal of Community Health, 10(1), 42-54. https://doi.org/10.1007/BF01321358

Maneesriwongul, W., \& Dixon, J. K. (2004). Instrument translation process: a methods review. Journal of Advanced Nursing, 48(2), 175-186. https://doi.org/10.1111/j.1365-2648.2004.03185.x

Maqsood, A. S. A., Oweis, A. I., \& Hasna, F. S. (2012). Differences between patients' expectations and satisfaction with nursing care in a private hospital in Jordan. International Journal of Nursing Practice, 18(2), 140-146. https://doi.org/10.1111/j.1440-172X.2012.02008.x

Meakin, R., \& Weinman, J. (2002). The 'Medical Interview Satisfaction Scale' (MISS-21) adapted for British general practice. Fam Pract, 19(3), 257-263. https://doi.org/10.1093/fampra/19.3.257

Mohammad, K. I., Alafi, K. K., Mohammad, A. I., Gamble, J., \& Creedy, D. (2013). Jordanian women's dissatisfaction with childbirth care. International Nursing Review, 61(2), 278-284. https://doi.org/10.1111/inr.12102

Moher, D., Liberati, A., Tetzlaff, J., Altman, D. G., \& The, P. G. (2009). Preferred reporting items for systematic reviews and meta-analyses: the PRISMA Statement. Open Medicine, 3(3), e123-e130.

Monazea, E. M. M., \& Al-Attar, G. S. T. (2015). Quality of delivery care in Assiut University Hospital, Egypt: mothers' satisfaction. The Journal of the Egyptian Public Health Association, 90(2), 64-71. https://doi.org/10.1097/01.EPX.0000466380.29269.4b

Mosallam, M., Rizk, D. E. E., Thomas, L., \& Ezimokhai, M. (2004). Women's attitudes towards psychosocial support in labour in United Arab Emirates. Archives of Gynecology and Obstetrics, 269(3), 181-187. https://doi.org/10.1007/s00404-002-0448-7

Moudi, Z., \& Tavousi, M. (2016). Evaluation of Mackey Childbirth Satisfaction Rating Scale in Iran: What Are the Psychometric Properties? Nursing and Midwifery Studies, 5(2). doi:https://dx.doi.org/10.17795\%2Fnmsjournal29952

Nassar, A. H., Awwad, J., Khalil, A. M., Abu-Musa, A., Mehio, G., \& Usta, I. M. (2007). A randomised comparison of patient satisfaction with vaginal and sublingual misoprostol for induction of labour at term. BJOG: An International Journal of Obstetrics and Gynaecology, 114(10), 1215-1221. https://doi.org/10.1111/j.1471-0528.2007.01492.x

Oweis, A. (2009). Jordanian mother's report of their childbirth experience: Findings from a questionnaire survey. International Journal of Nursing Practice, 525-533. https://doi.org/10.1111/j.1440-172X.2009.01774.x

Perriman, N., \& Davis, D. (2016). Measuring maternal satisfaction with maternity care: A systematic integrative review: What is the most appropriate, reliable and valid tool that can be used to measure maternal satisfaction with continuity of maternity care? Women and Birth, 29(3), 293-299. http://dx.doi.org/10.1016/j.wombi.2015.12.004

Ravi, R., \& Filani, T. O. (2002). Patient satisfaction of the Obstetric and Gynecology Unit at King Khalid University Hospital, Riyadh, Kingdom of Saudi Arabia. Saudi Medical Journal, 23(1). 
Rizk, D. E., Nasser, M., Thomas, L., \& Ezimokhai, M. (2001). Women's perceptions and experiences of childbirth in United Arab Emirates. Journal of Perinatal Medicine, 29(4), 298-307. https://doi.org/10.1515/JPM.2001.043

Rizk, D. E. E., El-Zubeir, M. A., Al-Dhaheri, A. M., Al-Mansouri, F. R., \& Al-Jenaibi, H. S. (2005). Determinants of women's choice of their obstetrician and gynecologist provider in the UAE. Acta Obstetricia Et Gynecologica Scandinavica, 84(1), 48-53. https://doi.org/10.1111/j.0001-6349.2005.00705.x

Sawyer, A., Ayers, S., Abbott, J., Gyte, G., Rabe, H., \& Duley, L. (2013). Measures of satisfaction with care during labour and birth: a comparative review. BMC Pregnancy and Childbirth, 13(108). https://doi.org/10.1186/1471-2393-13-108

Shaban, I., Mohammad, K., \& Homer, C. (2016). Development and Validation of Women's Satisfaction With Hospital-Based Intrapartum Care Scale in Jordan. Journal of Transcultural Nursing, 27(3), 256-261. https://doi.org/10.1177/1043659614550486

Shabila, N. P., Ahmed, H. M., \& Yasin, M. Y. (2014). Women's views and experiences of antenatal care in Iraq: A Q methodology study. BMC Pregnancy and Childbirth, 14(43). https://doi.org/10.1186/1471-2393-14-43

Shabila, N. P., Ahmed, H. M., \& Yasin, M. Y. (2015). Assessment of women's perspectives and experiences of childbirth and postnatal care using Q-methodology. Eastern Mediterranean Health Journal, 21(9), 647-654.

Sitzia, J., \& Wood, N. (1997). Patient satisfaction: a review of issues and concepts. Social science \& medicine, 45(12), 1829-1843. https://doi.org/10.1016/S0277-9536(97)00128-7

Van Teijlingen, E. R., Hundley, V., Rennie, A.-M., Graham, W., \& Fitzmaurice, A. (2003). Maternity Satisfaction Studies and Their Limitations: "What Is, Must Still Be Best". Birth, 30(2), 75-82. https://doi.org/10.1046/j.1523-536X.2003.00224.X

Ware, J. E., Jr., Snyder, M. K., Wright, W. R., \& Davies, A. R. (1983). Defining and measuring patient satisfaction with medical care. Eval Program Plann, 6(3-4), 247-263. https://doi.org/10.1016/0149-7189(83)90005-8

Worldatlas. (2018). Arabic Speaking Countries. $\quad$ Retrieved from https://www.worldatlas.com/articles/arabic-speaking-countries.html 


\section{Appendix 1. Characteristics of included surveys}

\begin{tabular}{|c|c|c|c|c|c|c|c|c|c|c|c|}
\hline \multirow[b]{2}{*}{ Author } & \multicolumn{3}{|l|}{ Survey } & \multicolumn{2}{|l|}{ Survey Construction } & \multicolumn{2}{|l|}{ Reliability } & \multicolumn{4}{|l|}{ Validity } \\
\hline & Name & $\begin{array}{l}\text { N. of } \\
\text { items/scal } \\
\text { e points }\end{array}$ & Dimensions & Item generation & Pilot testing & $\begin{array}{l}\text { consistency } \\
\text { (Cronbach's } \\
\text { alpha) }\end{array}$ & $\begin{array}{l}\text { Test-r } \\
\text { e-test }\end{array}$ & Face & Content & Criterion & Construct \\
\hline $\begin{array}{l}\text { (Bashour } \\
\text { et al., } \\
2013)\end{array}$ & $\begin{array}{l}\text { Modified } \\
\text { Medical Interview } \\
\text { Satisfaction Scale }\end{array}$ & $21 / 5$ & $\begin{array}{l}\text { NR, but focused on Doctor- } \\
\text { woman relationship }\end{array}$ & $\begin{array}{l}\text { The English survey items } \\
\text { developed through } \\
\text { literature review }\end{array}$ & $\begin{array}{l}\mathrm{NR} \text { (for the } \\
\text { Arabic version) }\end{array}$ & NR & NR & NR & NR & NR & NR \\
\hline $\begin{array}{l}\text { (Kabakia } \\
\text { n-Khasho } \\
\text { lian et al., } \\
\text { 2017) }\end{array}$ & $\begin{array}{l}\text { Adapted version of } \\
\text { the Mackey } \\
\text { Childbirth } \\
\text { Satisfaction Rating } \\
\text { Scale }\end{array}$ & $31 / 5$ & $\begin{array}{l}\text { Six dimensions capturing } \\
\text { aspects related to self, partner, } \\
\text { baby, nurse, midwife, physician, } \\
\text { and general rating scale }\end{array}$ & $\begin{array}{l}\text { The English survey items } \\
\text { developed through } \\
\text { literature review }\end{array}$ & $\begin{array}{l}\text { Tested in three } \\
\text { sites }\end{array}$ & 0.95 & NR & NR & NR & NR & NR \\
\hline $\begin{array}{l}\text { (Moham } \\
\text { mad et } \\
\text { al., 2013) }\end{array}$ & $\begin{array}{ll}\text { Satisfaction } & \text { with } \\
\text { Childbirth } & \text { Care } \\
\text { Scale } & \end{array}$ & & $\begin{array}{l}\text { Two dimensions: interpersonal } \\
\text { care by the midwife/doctor and } \\
\text { women's satisfaction with the } \\
\text { information received and } \\
\text { involvement in decision-making }\end{array}$ & $\begin{array}{l}\text { The English survey items } \\
\text { were developed through } \\
\text { literature review }\end{array}$ & $\begin{array}{l}\text { Tested on } 20 \\
\text { women }\end{array}$ & 0.81 & NR & $\begin{array}{l}20 \\
\text { women }\end{array}$ & $\begin{array}{l}\text { Experts in } \\
\text { midwifery } \\
\text { and } \\
\text { nursing. }\end{array}$ & NR & NR \\
\hline $\begin{array}{l}\text { (Mosalla } \\
\mathrm{m} \text { et al., } \\
2004)\end{array}$ & 27-items survey & $27 / 5$ & $\begin{array}{l}\text { Women attitudes and preferences } \\
\text { regarding psychosocial support } \\
\text { and antenatal preparation for } \\
\text { delivery and about their overall } \\
\text { satisfaction }\end{array}$ & Literature review & $\begin{array}{l}\text { Tested on } 20 \\
\text { mothers }\end{array}$ & NR & NR & NR & NR & NR & NR \\
\hline $\begin{array}{l}\text { (Oweis, } \\
\text { 2009) }\end{array}$ & $\begin{array}{l}\text { Satisfaction with } \\
\text { Childbirth } \\
\text { Experience } \\
\text { (SWCBE) }\end{array}$ & $32 / 5$ & NR & Literature review & $\begin{array}{l}\text { Tested on } 30 \\
\text { women }\end{array}$ & 0.88 & NR & NR & $\begin{array}{l}\text { By three } \\
\text { nursing } \\
\text { experts }\end{array}$ & NR & NR \\
\hline $\begin{array}{l}\text { (D. E. } \\
\text { Rizk et } \\
\text { al., 2001) }\end{array}$ & 23-items survey & $23 / 5$ & $\begin{array}{l}\text { Knowledge and perception of } \\
\text { childbirth }\end{array}$ & Literature review & $\begin{array}{l}\text { Tested on } 20 \\
\text { mothers. }\end{array}$ & NR & NR & NR & NR & NR & NR \\
\hline
\end{tabular}




\begin{tabular}{|c|c|c|c|c|c|c|c|c|}
\hline $\begin{array}{l}\text { (Shaban } \\
\text { et al., 14-items survey } \\
\text { 2016) }\end{array}$ & $14 / \mathrm{NR}$ & $\begin{array}{l}\text { Interpersonal care, satisfaction } \\
\text { with information and Literature review } \\
\text { involvement in decision making, } \\
\text { and physical birth environment }\end{array}$ & $\begin{array}{l}\text { Tested o1 } \\
\text { women }\end{array}$ & ${ }^{20} 0.88$ & NR & NR & $\begin{array}{l}\text { By seven } \\
\text { clinicians }\end{array}$ & $\begin{array}{l}\text { All items } \\
\text { exhibited } \\
\text { factor loading } \\
\text { of } 0.53 \text { or } \\
\text { more. }\end{array}$ \\
\hline
\end{tabular}

\section{Note. $\mathrm{NR}=$ Not Reported, PCA $=$ Principal Components Analysis}

\section{Appendix 2. Excluded studies and reasons for exclusion}

\begin{tabular}{|c|c|}
\hline Author & Why excluded \\
\hline (Awadalla, Kamel, Mahfouz, \& Refaat, 2009) & Not specific to satisfaction about childbirth care \\
\hline (Benage, Greenough, Vinck, Omeira, \& Pham, 2015) & Not specific to satisfaction about childbirth care \\
\hline (Bougmiza et al., 2011) & Not specific to satisfaction about childbirth care \\
\hline (Ghobashi \& Khandekar, 2008) & Not specific to satisfaction about childbirth care \\
\hline (Kamil \& Khorshid, 2013) & Not specific to satisfaction about childbirth care \\
\hline (Kempe, Noor-Aldin Alwazer, \& Theorell, 2010) & Women authority not satisfaction \\
\hline (R. Khresheh, 2010) & No survey used \\
\hline (Reham Khresheh, Almalik, Owies, \& Barclay, 2018) & No survey used \\
\hline (Langer et al., 2002) & Not specific to satisfaction about childbirth care \\
\hline (Maqsood, Oweis, \& Hasna, 2012) & Not specific to childbirth. All specialities were included \\
\hline (Monazea \& Al-Attar, 2015) & Full text was not accessible \\
\hline (Nassar et al., 2007) & Focus on labour pain not overall experience \\
\hline (Ravi \& Filani, 2002) & A letter to the editor \\
\hline (D. E. E. Rizk, El-Zubeir, Al-Dhaheri, Al-Mansouri, \& Al-Jenaibi, 2005) & Not specific to satisfaction about childbirth care \\
\hline (Nazar P. Shabila, Ahmed, \& Yasin, 2014) & No survey used \\
\hline (N. P. Shabila, Ahmed, \& Yasin, 2015) & No survey used \\
\hline
\end{tabular}

\section{Copyrights}

Copyright for this article is retained by the author(s), with first publication rights granted to the journal.

This is an open-access article distributed under the terms and conditions of the Creative Commons Attribution license (http://creativecommons.org/licenses/by/4.0/). 